\title{
Training Mouse Pathologists: 15 Years of Workshops on the Pathology of Mouse Models of Human Disease
}

\author{
John P. Sundberg ${ }^{1}$, Kelli Boyd ${ }^{2}$, Harm HogenEsch ${ }^{3}$, Alexander Yu. Nikitin ${ }^{4}$, Piper M. \\ Treuting $^{5}$, and Jerrold M. Ward ${ }^{6}$ \\ ${ }^{1}$ The Jackson Laboratory, Bar Harbor, ME \\ 2Departments of Comparative Medicine and Pathology, Vanderbilt University, Nashville, TN \\ ${ }^{3}$ Purdue University College of Veterinary Medicine, West Lafayette, IN \\ ${ }^{4}$ Cornell University College of Veterinary Medicine, Ithaca, NY \\ ${ }^{5}$ Departments of Comparative Medicine and Pathology, University of Washington, Seattle, WA \\ ${ }^{6}$ Global VetPathology, Montgomery Village, MD
}

\section{Keywords}

mouse pathology; conference summary; histopathology; databases

\begin{abstract}
On 3-7 October 2016 the $15^{\text {th }}$ annual workshop, Pathology of Mouse Models of Human Disease, was held at the High Seas Conference Center at The Jackson Laboratory in Bar Harbor, ME. The objective of this workshop was to cover phenotyping mouse models of human disease from the pathologist's perspective and to provide veterinary and human pathologists and pathology residents an overview of the latest technologies ranging from creating mouse models with genetic engineering technologies to evaluating them at the molecular, physiological, and histopathological levels. The meeting discussed the use of mice for modelling human disease for understanding the causes and pathogenesis (mechanisms) of disease, developing therapies, and methods of prevention. Discussions included all disease classifications - genetic, infectious, immune mediated, degenerative, aging, cardiovascular, cancer, and many others, focusing on specific models developed by the faculty.
\end{abstract}

The laboratory mouse has been critical to biomedical research since Clarence Cook Little defied the thoughts of the day nearly a century ago by creating the first inbred mouse strain ${ }^{1}$. Over the last 50 years the laboratory mouse has become the standard biomedical research model organism to study for a wide variety of human diseases. While fish, worms, flies, and other non-mammalian species also serve this purpose, most lack critical anatomical structures or physiological processes found in humans and mice, which limits many types of

Address correspondence to: John P. Sundberg, D.V.M., Ph.D., The Jackson Laboratory, 600 Main Street, Bar Harbor, ME 04609-1500, USA; john.sundberg@jax.org.

Declaration of Conflict of Interest: Dr. Sundberg has a research contract with BIOCON LLC which has no relevance to this meeting. The other authors state no conflicts of interest. 
investigations, especially translational studies. Over $60 \%$ of the National Institutes of Health (NIH)-funded research involves rodents, with mice representing $80-90 \%$ of the animals used $^{2}$. Detailed characterization of the mouse genome and extensive sets of tools available for genetic modifications also assure continuous use of the mouse as the leading model organism.

Spontaneous (naturally occurring) mutations in mice were, for many years, the unique, albeit relatively rare, source of new mouse biomedical models. The advent of genetically engineered mice (GEMs), which includes transgenesis (moving genes from one species to another or overexpressing a gene), targeted mutagenesis (so-called knockout mice), inducible models with or without molecular markers, and more recent endonuclease modified models, continue to make the laboratory mouse a very utilitarian biological tool. Breakthroughs using mouse models have provided crucial insight into the pathogenesis of numerous diseases affecting all organ systems. These technologies evolved from small scale projects within principal investigator's research laboratories, to large-scale international projects such as the Knockout Mouse Project (KOMP) which aims to create GEMs where ultimately every known protein coding gene in the mouse is inactivated ${ }^{3}$. Other large-scale projects include aging studies ${ }^{4,5}$, mutagenesis strategies 6,7 , and new approaches to generate genetically diverse outbred stocks (diversity outcross) ${ }^{8}$ and inbred strains (collaborative cross $)^{9}$. Accurate evaluation and interpretation of these mice requires clinical evaluation, gross necropsy, and histopathological phenotyping ${ }^{10}$. Comparison of the diseases these mice develop to human disease, to find the best fit, the so-called "Cinderella effect" 11 , involves collaboration between veterinarians, who understand the mouse disease and lesions, and physicians, who deal with the human patients. While the technologies to create mutant mice have become more or less routine, there remains a critical shortage of expert pathologists to do the requisite pathology-based phenotyping in which accurate interpretation of lesions are made combined with comparisons with human diseases ${ }^{12}$.

Veterinary pathologists are trained in the gross and histopathology of multiple species but have limited knowledge of human pathology, and their experience with laboratory mice is generally restricted to the diagnosis of infectious disease in standard domestic and research animals. Many veterinary pathologists gain expertise in toxicologic pathology while evaluating rodent tissues for the pharmaceutical and chemical industries, but, in general, they are not trained in the nuances of mouse genetics or the types of lesions to be expected in GEMs. By contrast, physicians have extensive knowledge of human disease but are not well versed in the intricacies of mouse anatomy, pathology, and genetics or the concept of comparative pathology. Both groups, physicians and veterinarians, have the basic skills to generate high quality evaluation of mouse models, but all need the confidence they can do this.

To address this issue, the first large meeting, Pathology of Genetically Engineered Mice, was held in 1999 at the NIH in Bethesda, Maryland. This meeting resulted in the production of a well-regarded textbook ${ }^{13}$, and additional books (Table 1) and reviews have subsequently provided traditional resources. Many pathologists working with mice do so in small groups or in isolation at their institutions. The small workshop format of the Pathology of Mouse Models of Human Disease Workshops, consisting of 20-25 participants and 15 or more 
faculty (Figure 1), is designed to encourage interaction among all participants, and has resulted in the development of many collaborations and, perhaps more importantly, confidence for the attendees to seek consultation with the faculty. Variations in this format are now commonly used in similar meetings around the world, often involving the organizers of this series.

The workshop format has evolved to include open evening discussions on cases or research projects using whole slide scanned images. Presentations cover mouse genetics and genetic nomenclature, didactic sessions covering specific diseases and organ systems, embryonic lethal analyses, stem cell and regenerative medicine, technologies for creating GEMs, and the most current physiological and imaging systems to systematically evaluate mouse models. Wet labs on necropsy procedures or new technologies were provided. The core faculty, consisting of experts in their respective areas of mouse pathology from 6 different veterinary and medical colleges and research institutions, described the latest breakthroughs in their fields. The workshop also included discussions on grantsmanship, manuscript writing, and dealing with editors. Dr. Matthew H. Kaufman (University of Edinburgh in Scotland) was a regular speaker on mouse embryology for many years ${ }^{14,15}$. He was well known as one of the pioneers in stem cell culturing methods ${ }^{16}$. In his memory, the third annual Professor Kaufman Stem Cell Lecture was given by Dr. Rudolf Jaenisch (Whitehead Institute, MIT) during the 2016 course.

Speakers not only lectured on their own work but provided group and individual demonstrations on the use of mouse-centric databases such as The Mouse Genome Informatics Database (http://informatics.jax.org/); the Mouse Tumor Biology Database (http://tumor.informatics.jax.org/); Mouse Phenome Database (http://phenome.jax.org/), Pathbase (http://pathbase.net/); the Mouse Disease Information System (MoDIS) ${ }^{17}, 18$.

These annual workshops provide a state-of-the-art overview of the pathology of GEMs and other mouse models of human disease as well as spontaneous diseases affecting aging inbred strains and results of experimental manipulations. More importantly, the workshops allow for the integration of this field with other research areas such as genetics and molecular biology. Of even greater significance, the workshops promote and strengthen effective working relationships between veterinary and human pathologists, in which they join forces to make the most accurate histopathologic interpretations and the most creative uses of these fantastic biomedical tools. These meetings will continue to be held the first full week of October and at the High Seas Conference Center at The Jackson Laboratory in Bar Harbor, Maine.

\section{Acknowledgments}

The authors thank Erin McDevitt and Charles Wray, Courses and Meetings Department, The Jackson Laboratory, who provided critical logistical support to hold these workshops. This workshop series was supported directly or indirectly by grants from the National Institutes of Health (R13 OD010920; R01 CA089713, R01CA197160, R01CA182413), Midcareer Awards in Mouse Pathobiology (K26 RR000173 JPS; K26 RR017595, AYN), NYSTEM (C028125 and C029155, AYN), and Howard Hughes Medical Institute (HHMI). 


\section{Abbreviations \\ GEMS genetically engineered mice \\ KOMP knockout mouse project \\ MoDIS Mouse Disease Information System \\ NIH the National Institutes of Health in the United States}

\section{References}

1. Holstein, J. The first fifty years at the Jackson Laboratory. The Jackson Laboratory; Bar Harbor: 1979.

2. Valli T, et al. Over $60 \%$ of NIH extramural funding involves animal-related research. Vet Pathol. 2007; 44:962-964. [PubMed: 18039915]

3. Abbott A. Mouse project to find each gene's role. Nature. 2010; 465:410. [PubMed: 20505705]

4. Sundberg JP, et al. The mouse as a model for understanding chronic diseases of aging: the histopathologic basis of aging in inbred mice. Pathobiol Aging Age Relat Dis. 2011; 1

5. Sundberg JP, et al. Approaches to investigating complex genomic traits in a large-scale inbred mouse aging study. Vet Pathol. 2016; 53:456-467. [PubMed: 26936752]

6. Clark AT, et al. Implementing large-scale ENU mutagenesis screens in North America. Genetica. 2004; 122:51-64. [PubMed: 15619961]

7. Goldowitz D, et al. Large-scale mutagenesis of the mouse to understand the genetic bases of nervous system structure and function. Brain Res Mol Brain Res. 2004; 132:105-115. [PubMed: 15582151]

8. Svenson, KL., Valdar, W., Braun, ML., Chesler, EJ., Churchill, GA. International Mouse Genome Conference; Lajolla, CA. 2009.

9. Chesler EJ, et al. The Collaborative Cross at Oak Ridge National Laboratory: developing a powerful resource for systems genetics. Mamm Genome. 2008; 19:382-389. [PubMed: 18716833]

10. Schofield PN, Vogel P, Gkoutos GV, Sundberg JP. Exploring the elephant: histopathology in highthroughput phenotyping of mutant mice. Dis Models Mech. 2012; 5:19-25.

11. Sundberg JP, Roopenian DC, Liu ET, Schofield PN. The Cinderella effect: Searching for the best fit between mouse models and human diseases. J Invest Dermatol. 2013; 133:2509-2513. [PubMed: 23812235]

12. Schofield PN, et al. PRIME importance of pathology expertise. Nat Biotechnol. 2009; 27:24-25. [PubMed: 19131991]

13. Ward, JM., Mahler, J., Maronpot, R., Sundberg, JP. Pathology of genetically engineered mice. Iowa State University Press; Ames: 2000.

14. Kaufman, MH. The atlas of mouse development. Academic Press; London: 1992.

15. Kaufman, MH., Bard, JBL. The anatomical basis of mouse development. Academic Press; San Diego: 1999.

16. Evans MJ, Kaufman MH. Establishment of pluripotential cells from mouse embryos. Nature. 1981; 292:154-156. [PubMed: 7242681]

17. Sundberg JP, Sundberg BA, Schofield PN. Integrating mouse anatomy and pathology ontologies into a diagnostic/phenotyping database: tools for record keeping and teaching. Mammalian Genome. 2008; 19:413-419. [PubMed: 18797968]

18. Sundberg BA, Schofield PN, Gruenberger M, Sundberg JP. A data capture tool for mouse pathology phenotyping. Vet Pathol. 2009; 46:1230-1240. [PubMed: 19605915] 


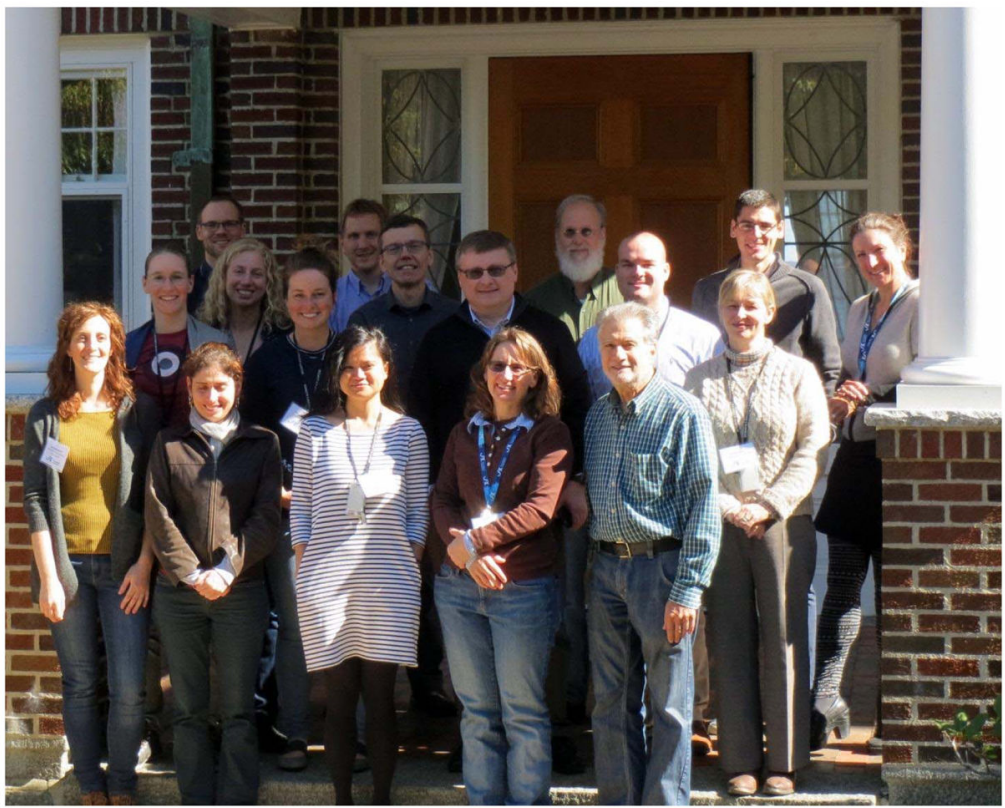

Figure 1.

Participants in the 2016, 15th annual Pathology of Mouse Models of Human Disease course outside the High Seas Conference Center in Bar Harbor, ME. Front row - Sara Santagostino, Ana Vieira, May Tse Pui-ying, Kelli Boyd, Jerry Ward; Second row - Nadine Stokar, Alexandria Schauer, Alex Nikitin, Frances Henson; Third row - Jennifer Peirick, Harm Hogenesch,Steve Davison, Piper Treuting; Fourth row - Dustin Graham, Tim Helms, John Sundberg, Ryan Schafbuch; not present - Lauren Himmel, Pankaj Kumar, Ahn Diep, Kuldeep Singh, and Peter Vogel. 


\section{Table 1}

Textbooks relevant for pathologists studying animal model of human disease

\begin{tabular}{|c|c|c|}
\hline Editors & Title & Publisher \\
\hline Bannsch P, Gossener W & $\begin{array}{l}\text { Pathology of Neoplasia and Preneoplasia in } \\
\text { Rodents. Vol } 1 \text { and } 2\end{array}$ & Stuttgart: Schattauer; 1997 \\
\hline Bolon B & $\begin{array}{l}\text { Pathology of the Developing Mouse: A Systematic } \\
\text { Approach. }\end{array}$ & Boca Raton, FL: CRC Press; 2015 \\
\hline $\begin{array}{l}\text { Croy BA, Yamada A T, DeMayo } \\
\text { FJ, et al. }\end{array}$ & The Guide to Investigation of Mouse Pregnancy & London, Elsevier; 2014 \\
\hline Frith CH, Ward JM & $\begin{array}{l}\text { Color Atlas of Neoplastic and Non- neoplastic } \\
\text { Lesions in Aging Mice }\end{array}$ & Amsterdam: Elsevier; 1988 \\
\hline $\begin{array}{l}\text { Fox JG, Barthold SW, Davisson } \\
\text { MT, et al. }\end{array}$ & $\begin{array}{l}\text { The Mouse in Biomedical Research. Vol 1. History, } \\
\text { Wild Mice, and Genetics. } 2^{\text {nd }} \text { ed. }\end{array}$ & San Diego, CA: Academic Press; 2007 \\
\hline $\begin{array}{l}\text { Fox JG, Barthold SW, Davisson } \\
\text { MT, et al. }\end{array}$ & $\begin{array}{l}\text { The Mouse in Biomedical Research. Vol } 2 . \\
\text { Diseases. } 2^{\text {nd }} \text { ed. }\end{array}$ & San Diego, CA: Academic Press; 2007 \\
\hline $\begin{array}{l}\text { Fox JG, Barthold SW, Davisson } \\
\text { MT, et al. }\end{array}$ & $\begin{array}{l}\text { The Mouse in Biomedical Research. Vol } 3 . \\
\text { Normative Biology, Husbandry, and Models. } 2^{\text {nd }} \\
\text { ed. }\end{array}$ & San Diego, CA: Academic Press; 2007 \\
\hline $\begin{array}{l}\text { Fox JG, Barthold SW, Davisson } \\
\text { MT, et al. }\end{array}$ & $\begin{array}{l}\text { The Mouse in Biomedical Research. Vol } 4 . \\
\text { Immunology. } 2^{\text {nd }} \text { ed. }\end{array}$ & San Diego, CA: Academic Press; 2007 \\
\hline Green EL & Biology of the Laboratory Mouse. $2^{\text {nd }}$ ed. & New York, NY: Dover Publications; 1968 \\
\hline $\begin{array}{l}\text { Haschek WM, Rousseaux CG, } \\
\text { Wallig MA }\end{array}$ & Handbook of Toxicologic Pathology. 2nd ed. & San Diego, CA: Academic Press; 2013 \\
\hline Hedrich HJ & The Laboratory Mouse. $2^{\text {nd }}$ ed. & London: Academic Press; 2012 \\
\hline Holland EC & Mouse Models of Human Cancer & Hoboken, NJ: Wiley-Liss; 2004 \\
\hline $\begin{array}{l}\text { Iwaki T, Yamashita H, Hayakawa } \\
\mathrm{T}\end{array}$ & A Color Atlas of Sectional Anatomy of the Mouse & Tokyo: Maruzen Publishing Company; 2001 \\
\hline Jones TC, Hackel DB, Migaki G & Handbook: animal models of human diseases & $\begin{array}{l}\text { Washington, D.C.: Armed Forces Institute of } \\
\text { Pathology, } 1972 .\end{array}$ \\
\hline Jones TC, Mohr U, Hunt RD & $\begin{array}{l}\text { Monographs on Pathology of Laboratory Animals: } \\
\text { Endocrine System }\end{array}$ & Berlin: Springer-Verlag, 1983 \\
\hline Jones TC, Mohr U, Hunt RD & $\begin{array}{l}\text { Monographs on Pathology of Laboratory Animals: } \\
\text { Respiratory System }\end{array}$ & Berlin: Springer-Verlag, 1985 \\
\hline Jones TC, Mohr U, Hunt RD & $\begin{array}{l}\text { Monographs on Pathology of Laboratory Animals: } \\
\text { Urinary System }\end{array}$ & Berlin: Springer-Verlag, 1986 \\
\hline Jones TC, Mohr U, Hunt RD & $\begin{array}{l}\text { Monographs on Pathology of Laboratory Animals: } \\
\text { Genital System }\end{array}$ & Berlin: Springer-Verlag, 1987 \\
\hline Jones TC, Mohr U, Hunt RD & $\begin{array}{l}\text { Monographs on Pathology of Laboratory Animals: } \\
\text { Nervous System }\end{array}$ & Berlin: Springer-Verlag, 1988 \\
\hline Jones TC, Mohr U, Hunt RD & $\begin{array}{l}\text { Monographs on Pathology of Laboratory Animals: } \\
\text { Integument and Mammary Glands }\end{array}$ & Berlin: Springer-Verlag, 1989 \\
\hline Jones TC, Mohr U, Hunt RD & $\begin{array}{l}\text { Monographs on Pathology of Laboratory Animals: } \\
\text { Hematopoietic System }\end{array}$ & Berlin: Springer-Verlag, 1990 \\
\hline Jones TC, Mohr U, Hunt RD & $\begin{array}{l}\text { Monographs on Pathology of Laboratory Animals: } \\
\text { Cardiovascular and Musculoskeletal System }\end{array}$ & Berlin: Springer-Verlag, 1991 \\
\hline Jones TC, Mohr U, Hunt RD & $\begin{array}{l}\text { Monographs on Pathology of Laboratory Animals: } \\
\text { Eye and Ear }\end{array}$ & Berlin: Springer-Verlag, 1991 \\
\hline Jones TC, Popp JA, Mohr U & $\begin{array}{l}\text { Monographs on Pathology of Laboratory Animals: } \\
\text { Digestive System, } 2^{\text {nd }} \text { edition }\end{array}$ & Berlin: Springer-Verlag, 1997 \\
\hline
\end{tabular}




\begin{tabular}{|c|c|c|}
\hline Editors & Title & Publisher \\
\hline Kaufman MH & The Atlas of Mouse Development. 2nd ed. & San Diego, CA: Academic Press; 1992 \\
\hline Kaufman MH, Bard JBL & The Anatomical Basis of Mouse Development. & San Diego, CA: Academic Press; 1999 \\
\hline $\begin{array}{l}\text { Kaufman MH, Nikitin AY, } \\
\text { Sundberg JP }\end{array}$ & $\begin{array}{l}\text { Histologic Basis of Mouse Endocrine System } \\
\text { Development: A Comparative Analysis. }\end{array}$ & Boca Raton, FL: CRC Press, 2010 \\
\hline Maronpot RR & Pathology of the Mouse: Reference and Atlas. & Vienna, IL: Cache River Press; 1999 \\
\hline McInnes, EF & $\begin{array}{l}\text { Background Lesions in Laboratory Animals: A } \\
\text { Color Atlas }\end{array}$ & Edinburgh, UK; Saunders (Elsevier), 2012 \\
\hline Mohr U & $\begin{array}{l}\text { International Classification of Rodent Tumours: } \\
\text { The Mouse. }\end{array}$ & Berlin, Germany: Springer-Verlag; 2001 \\
\hline $\begin{array}{l}\text { Mohr U, Dungworth CC, Capen } \\
\text { CC, et al. }\end{array}$ & Pathobiology of the Aging Mouse. Vol 1 and 2. & Washington, D.C.: ILSI Press; 1996 \\
\hline Percy DH, Barthold SW & $\begin{array}{l}\text { Pathology of Laboratory Rodents and Rabbits. 4th } \\
\text { ed. }\end{array}$ & Ames, IA: Iowa Wiley Blackwell; 2016. \\
\hline Papaioannou VE, Behringer RR & $\begin{array}{l}\text { Mouse Phenotypes. A Handbook of Mutation } \\
\text { Analysis }\end{array}$ & $\begin{array}{l}\text { Cold Spring Harbor, NY: Cold Spring Harbor } \\
\text { Press; } 2005\end{array}$ \\
\hline Popesko P, Rajitov V, Hork J & $\begin{array}{l}\text { A Color Atlas of Anatomy of Small Laboratory } \\
\text { Animals }\end{array}$ & London: Wolfe Publishing, Ltd., 1992. \\
\hline Proetzel G, Wiles MV & Mouse Models for Drug Discovery. $2^{\text {nd }} e d$. & New York, NY: Humana Press; 2016 \\
\hline Ruberte J, Carretero A, Navarro M & $\begin{array}{l}\text { Morphologic Mouse Phenotyping. Anatomy, } \\
\text { Histology, and Imaging }\end{array}$ & Madrid: Editorial Medica Panamericana; 2016 \\
\hline Scudamore CL & A Practical Guide to the Histology of the Mouse. & Oxford, UK: John Wiley \& Sons; 2013 \\
\hline Silver LM & Mouse Genetics & New York, NY: Oxford University Press; 1995 \\
\hline $\begin{array}{l}\text { Smith RS, John SWM, Nishina } \\
\text { PM, et al. }\end{array}$ & $\begin{array}{l}\text { Systematic Evaluation of the Mouse Eye. Anatomy, } \\
\text { Pathology, and Biomethods }\end{array}$ & Boca Raton, FL: CRC Press; 2002 \\
\hline Sundberg JP & $\begin{array}{l}\text { Handbook of Mouse Mutations With Skin and Hair } \\
\text { Abnormalities: Animal Models and Biomedical } \\
\text { Tools. }\end{array}$ & Boca Raton, FL: CRC Press; 1994 \\
\hline Sundberg JP, Boggess D & $\begin{array}{l}\text { Systematic Approach to Evaluation of Mouse } \\
\text { Mutations. }\end{array}$ & Boca Raton, FL: CRC Press; 2000 \\
\hline Sundberg JP, Ichiki T & Genetically Engineered Mice Handbook. & Boca Raton, FL: CRC Press; 2006 \\
\hline Treuting PM., Dintzis, SM & $\begin{array}{l}\text { Comparative Anatomy and Histology: A Mouse } \\
\text { and Human Atlas }\end{array}$ & San Diego, CA: Academic Press; 2011 \\
\hline $\begin{array}{l}\text { Ward JM, Mahler JF, Maronpot } \\
\text { RR, Sundberg JP }\end{array}$ & Pathology of Genetically Engineered Mice. & Ames, IA: Iowa State University Press; 2000 \\
\hline
\end{tabular}

